\title{
Management of Entrepreneurial Orientation Tendencies in Artisanal Oil Refineries and Nigeria's National Growth
}

\author{
Soye Peniel Asawo, PhD
}

Rivers State University of Science and Technology, Port Harcourt, Nigeria

doi: 10.19044/esj.2016.v12n25p236 URL:http://dx.doi.org/10.19044/esj.2016.v12n25p236

\begin{abstract}
Nigeria's oil economy is facing lingering crises and the oil rich Niger Delta region of the country is dotted with illegal artisanal oil refineries with attendant economic, environmental and social consequences for the country. This paper identifies entrepreneurial orientation tendencies exhibited by the operators of these refineries and examines how these tendencies can be managed towards the enhancement of national development. The study adopted the ideographic research methodology, generating textual data from personal observation and series of written reports on the operations of the artisanal oil refineries, and the statements of critical stakeholders including government agents, community leaders and ex-agitators in the Niger Delta region of Nigeria. The qualitative data was analyzed through the use of an issue-focused approach. The study concludes that there is a link between entrepreneurial orientation tendencies and national development and recommends that the Nigerian government should properly manage these entrepreneurial orientation tendencies to enhance national development.
\end{abstract}

Keywords: Entrepreneurial Orientation Tendencies, National Development, Artisanal oil refineries, Niger Delta Region

\section{Introduction}

At the close of the $20^{\text {th }}$ Century, Ake (1996 p. 1) posited that, "three decades of preoccupation with development in Africa have yielded meager returns". Today, Nigeria is faced with a barrage of socio-economic problems such as unemployment, crime, poverty, etc, at unprecedented levels with many begging question seeking answers. However, successive governments in Nigeria seem to be seeking external answers to internal problems. But Hofstede (1996 p. 432) instructively posited that "it has become painfully clear that development cannot be pressure-cooked" and that any assumption to the effect that outsiders can develop a country is not only arrogant but deplorable. Recently, efforts are being made to think out new and novel solutions to 
lingering problems in the Nigerian oil industry. Nigeria's oil economy seems to have brought more problems than anticipated at the inception of oil exploration in the country over five decades ago. Even though "there is tremendous interest in entrepreneurship around the world" (Barringer and Ireland, 2013, p. 30), which has heightened attention interest in entrepreneurship in Nigeria, not much has been done to address the lingering crises in Nigeria's oil economy from an entrepreneurial standpoint. There seems to be a glaring failure of the critical stakeholders to draw lessons from indigenous entrepreneurial practices in the quest to resolve these myriad of problem. The purpose of this paper is thus to examine how the indigenous entrepreneurial orientation tendencies exhibited in the operations of illegal artisanal oil refineries in the Niger Delta Region can be harnessed towards an amicable resolution of the Niger Delta Crises.

\section{Study Context}

The Niger Delta Region of Nigeria, where this study took place is home to more than 31 million people, made up of multiethnic nationalities (Boris, 2015), and with the major traditional primary occupation as farming and fishing. The region according to Wokocha (2002, p.12) "describes the fan formation arising from the spread of the distributaries at the base of the River Niger wherein it empties into the Atlantic Ocean". The region has been described as Nigeria's economic heartbeat (Derah 2001), and is made up of the southern coastal states covering an area of 70,000 square $\mathrm{km}$ with a number of distinct ecological zones (Fubara 2002). The region is rich with Crude Oil, which is the mainstay of the Nigerian economy (Ekuerhare 2002). "Nigeria, being a mono-economy nation largely depends on the oil sector for its economic survival" (Boris 2015, p.563). Fubara (2002) argues that even though the region contributes a lot to the sustenance of the Nigerian economy, it still has a gamut of human and infrastructural problems and remains the most uncared for. This neglect has left the Niger Delta populace feeling rejected and cheated, and this has led to series of agitations. "Consequently, the region is at present, averred to be very volatile as Multi-National Corporations (MNOCs) especially in the oil industry have suffered increased aggression from host communities for their perceived ethical inconsistencies towards alleviating the numerous problems of host communities" (Asawo, $2011 \mathrm{p} 78$ ).

The situation has degenerated to such a state that MNOCs are widely believed to represent imperial terror against the region (Derah, 2001). However, the Niger Delta Environmental Survey Phase 1 (1997, p.62) reports that "the people are becoming increasingly enlightened about their rights as citizens, in the same vein that they are becoming increasingly aware of how much is derived from their communities as oil revenues both for the government and the oil companies..." Consequently, Asawo (2011, p.78) 
posits that "there is increasing demand by the people of the region for a fair treatment towards the actualization of their dream of accelerated and sustainable development". Not getting the desired response, the people seem to have taken their own destiny in their hands by their actions, which may not be unconnected with the issue raised by Efemini (2002) that the people believe that with the huge wealth generated from their oil endowments, their current poor level of development is inexcusable. Accordingly, what initially seemed like minor economic crimes in the region have now culminated in extreme violence against the state. The activities of the Movement for the Actualization of the Niger Delta (MEND) in the last decade and the recent violent destruction of oil installations in the Niger Delta by the Niger Delta Avengers, which have almost grounded oil exploration in Nigeria, have received wide spread international reportage in the last one year.

Another dimension to the crises is the establishment of illegal artisanal oil refineries that get supplies from oil theft. While part of the stolen crude is shipped overseas through foreign collaborators part of it is refined locally in these illegal artisanal oil refineries that litter the creeks of the Niger Delta. Attah (2012) reports that oil theft and illegal artisanal refining in the Niger Delta grew since the end of the militant crises in 2009. These illegal artisanal oil refineries are fabricated locally with locally sourced materials and the refining process is most times very risky. This is confirmed by an eyewitness, Ofehe $(2009$, p.3) who in describing the refining process reported that the operators,

"buy crude oil from oil bunkering agents and store in reservoirs. The refinery has drums fitted to water container storages that act as coolants with pipes protruding from behind the makeshift furnaces. They make fire from locally collected woods which subject the drums (furnace) to extreme heat. The crude oil is heated to varying temperatures to get fuel, kerosene, diesel and associated gas."

The focus of this study is not on the morality of the operations of the illegal artisanal oil refineries in the Niger Delta, but rather the lessons that can be drawn from the indigenous entrepreneurial orientation tendencies that are exhibited in the operations of these illegal artisanal oil refineries in the quest for national development.

\section{Review of Concepts}

\section{Entrepreneurial Orientation Tendencies}

The question about who an entrepreneur has lingered through several centuries. There are several definitions in the literature that reflect the 
economic and social realities of their proponents. According to Drucker (1985 p. 23), "Entrepreneurship rests on a theory of economy and society", meaning that it is socially constructed. Ivancevich et al (1997) aver that Richard Cantillon, a French economist of Irish descent, popularized the concept of entrepreneurship in economics through his writing in 1755. Similarly, Stockes and Wilson (2010) state that Richard Cantillon (1734) defined entrepreneurship in economic terms from the view of Agency Theory; J. B. Say (1800s) from the resource based perspective; and Joseph Schumpeter (1934) from the perspective of innovation. Barringer and Ireland (2013, p.32) gave an apt definition of the concept of entrepreneurship as "the process by which individuals pursue opportunity without regard to resources they currently control".

This definition and most others are focused on the behavior and activities of the entrepreneur. Comparing entrepreneurs to men in general, Gannon (1988 p. 595) states that "entrepreneurs scored significantly higher on scales measuring their need to achieve, their independence, and the effectiveness of their leadership". The need for achievement, risk taking, independence, innovativeness, and drive are evident traits associated with the entrepreneur. The manifestation of these traits is determined by the entrepreneurial orientation and entrepreneurial environments within a given society. Entrepreneurial orientation is the central ideology held in an enterprise or society that determines their involvement in activities that seek to explore and exploit avenues to launch new ventures and in new ways. This determines to a large extent the level of entrepreneurship in any given society and according to Bateman and Snell (1999 p.260), the extent of "entrepreneurial orientation is determined by the following five tendencies: (1) to allow independent action, (2) innovative, (3) take risks, (4) be proactive and, (5) competitively aggressive.

Independent action means the liberty to exercise individual creativity in the expression of unique ideas necessary for advancement and the will to carry through with such ideas without fretting in the face of opposition. Innovativeness represents the level of support for new and creative ideas (Okpara, 2007). This is promoted by the level of experimentation and according to Bateman and Snell (1999 p. 260), "it requires a willingness to depart from existing practices and venture beyond the status quo". Risk taking is the willingness to venture into a relatively unknown sphere of endeavour. This, according to Hofstede, 1997 is determined by the uncertainty avoidance index score of a community. To be Proactive is to pre-empt future opportunities and threats and act in anticipation. According to Bateman and Snell (1999), it requires forward thinking and the ability to act fast. Unlike being reactionary, to be proactive involves determining events rather than follow them. An entrepreneur neither lets circumstances nor situations to set 
the agenda for them but they rather preempt the circumstances and situations and prepare ahead to take advantage of opportunities. Competitive Aggressiveness is the intensity with which a person challenges competitors in other to gain competitive advantage over them. Mohammed bin Rashid Al Maktoum, Vice President and Prime Minister of the United Arab Emirates and Ruler of Dubai, in his narrative of his vision illucidates the competitive aggressiveness thus:

"With each new day in Africa, a gazelle wakes up knowing he must outrun the fastest lion or perish. At the same time, a lion sirs and stretches, knowing he must outrun the fastest gazelle or starve. It is no different for the human race. Whether you consider yourself a gazelle or a lion, you simply have to run faster than others to survive" Al Maktoum (2012, p. 12).

Miller (1983) is reported to offer what appears to be the earliest operationalization of entrepreneurship orientation by defining an entrepreneurial firm as "one that engages in product marketing innovation, undertakes somewhat risky ventures, and is first to come up with proactive innovations, beating competitors to the punch" (Boohene et al 2012, p.78). These key tendencies of entrepreneurship underscores the point that the entrepreneur is somewhat different from a mere business owner for, as Drucker (1985 p. 23) states, entrepreneurship is "a distinct feature whether of an individual or an institution" and in Mintzberg's (1989, p. 128) conclusion, "it is very much tied up with the creation of strategic vision, often with the attainment of a new concept". Innovation and creativity have been closely associated with entrepreneurship. "Drucker (1985) for instance argued that innovation is the tool of entrepreneurship" and Okpara (2007, p.5) argues that "you cannot innovate without creativity".

\section{National Development}

Akinrinade and Barling (1987) as shown by Ahiauzu (2009) argue that no consensus has been arrived at on the development problematic with regard to the precise conceptualization of development or its measurement. Nonetheless, Nwinia (1993) views both concepts of growth and development as stages in national development. Distinguishing both concepts, Colombatto (2006, p.243) iterates that the economic literature "refers to growth when dealing with proportional changes in GDP or - more frequently - in GDP per capita; and to development when analyzing living standards - including features that do not necessarily form the object of monetary measurement". In their view, Todaro and Smith (2006, p.811) explain that economic growth is "the steady process by which the productive capacity of the economy is 
increased over time to bring about rising levels of national output and income". In other words, national development is inclusive of material wellbeing (Growth) measured by GDP per capita and other non-market activities (development) measured by non-monetary indices such as health, political stability and security, family life, community life, climate and geography, job security, political freedom, and gender equality.

\section{Methodology}

The study adopted the ideographic research methodology, generating textual data from personal observation and series of written reports on the operations of the artisanal oil refineries, and the statements of critical stakeholders including government agents, community leaders and exagitators in the Niger Delta region of Nigeria. The qualitative data was analyzed through the use of an issue-focused approach (Weiss, 1994). Bateman and Snell's (1999) five tendencies of entrepreneurial orientation formed the basis of analysis. The interviews were recorded, transcribed, coded, sorted and integrated. The textual data were coded and integrated to aid inferential interpretation with the data categories grounded in the observation reports similar to Strauss and Corbin's (1990) prescription for the data categories to be grounded in interview transcripts.

\section{Research Findings and Discussion}

Independent action: The establishment of illegal artisanal oil refineries that litter the mangrove forests of the Niger Delta region of Nigeria demonstrates individual action as these operations are for the benefit of the operators against the common good of the communities of the Niger Delta. They operate in isolation without community participation or endorsement. It has been argued that the African society is largely collectivistic and not individualistic (Ahiauzu, 1999), but even though the operators of the illegal artisanal refineries share in the communal living structure of the communities, they rely on their individuality for economic survival. Stakeholders believe that much can be achieved through the child rearing and educational systems in Nigeria when educators promote the individuality of each member of a social group while still emphasizing that the group is a refining platform for ideas generated by individuals. Drawing from this example it will not be out of place if individual Nigerians are empowered to bring to commerce, their individuality that will be subjected to community scrutiny, the outcome of which is collectively celebrated. Mbigi (1997, p.32) justifies this argument by positing that "in Afrocentric cultures and tribes, individual entrepreneurship is encouraged, nurtured, harnessed, celebrated collectively and highly respected, almost to the point of canonisation'. 
Innovativeness: The paradox in Nigeria, being an oil producing nation yet not being able to refine enough petroleum products to satisfy local consumption is a major course for concern to stakeholders who believe that the government has to encourage innovativeness to resolve the paradox. While the rest of the oil producing countries have modular refineries, Nigeria has none and the failure of the state has propelled the locals to establish illegal artisanal refineries, and by so doing demonstrating innovativeness. Though the outcome of the analysis shows that the metaphysical and theological approaches to understanding reality are still dominant in Nigeria's rural communities yet the spirit of industry has not been in short supply in these communities. Thus, even though the innovative mind in the western construction of the entrepreneurship emphasizes empiricism, a model can be recreated to capture the modes of knowledge generation in the indigenous Nigerian socio-cultural environment. For, Mbigi and Maree (2005, p.viii) argue that:

"Africa's achievements and genius do not lie in technology, but in social and spiritual spheres. If Africa is going to enter and win in the global economic arena, it will have to draw on its spiritual and social heritage. The beautiful things in Africa still have to be created."

The infusion of these traditional modes into the scientific thought process is likely to lead the Nigerian society to greater innovativeness. The richness of this innovative process can be enhanced if the right atmosphere is created and the 'local wisdom' and ingenuity of citizens are accommodated to enrich the content of empirical analyses.

Risk taking: Hofstede (1997, p.113) who defines uncertainty avoidance as "the extent to which the members of a culture feel threatened by uncertain or unknown situations" indicates a medium uncertainty avoidance score of 54 for West Africa. In spite of this record, which indicates that West African are neither extremely risk prone or averse, the entire illegal artisanal oil refineries episode is evidence that local Nigerians are risk prone. A local resident asked "what could be more risky than vandalizing highly combustible pipelines and transporting crude in locally fabricated wooden boats, or building local refineries and living in the wild creeks in defiance of the State?" The operators of the illegal artisanal oil refineries are daily under the surveillance of the state that deploys the security forces to fish out and prosecute offenders for economic crimes. The process of crude theft and refining, which is done without best safety standards are all very risky ventures and on several occasions, respondents say lives are lost. Yet these refineries thrive. The fear of the unknown has the potential to cripple lofty visions that could advance any society. The ability to take risk is what distinguishes the 
entrepreneur from all others. To advance entrepreneurship requires that the society consciously encourages citizens to take measured risk. According to the outcome of the analysis, Nigerian indigenous communities are structured to engender risk taking. The field report shows that in a typical coastland community for instance, children are giving hands-on training in fishing expedition and thus exposed to the risk of the high sea at a tender age. The same happens with the farming communities where children are allowed to confront the dangers of wild life early in life with no sophisticated weapons. If this culture of risk-taking is brought into commerce and industry, stakeholders believe that Nigerian entrepreneurs will take more intelligent and result oriented risks.

Being Proactive: The outcome of the analysis shows that the rural dwellers in Nigeria's traditional communities are by nature very instinctive. Thus they can take prompt actions to address issues. Stakeholders are however of the opinion that the impact of western education especially in the business schools have placed premium on planning and forecasting. Stakeholders who are entrepreneurship educators agree that emphasis in entrepreneurship studies have been on causality rather than effectuation. Sarasvathy (2001) identifies that an entrepreneur adopting the effectual logic begins with three categories of means, the first of which is who they are - their traits, tastes and abilities. This is in line with Mbigi and Maree's (2005) position that "in Afrocentric religion, in order to know what you can become you must start by knowing who you are" (Mbigi and Maree's, 2005 p.51). By knowing who they are, the Japanese took the global market by storm because they looked beyond the devastating circumstances brought about by the Second World War and the 1973 oil crises (Yew, 2000). The operators of these illegal artisanal oil refineries in the Niger Delta are both proactive and effectual as respondents confirm that these operators identify the oil resources in their domain, the local materials used for the fabrication of the refineries, and their knowledge, skills and abilities (KSAs) as their means. Nigeria, like other hitherto 'third world countries' such as South Korea, Singapore, Malaysia, Indonesia and the United Arab Emirates can, by being proactive and effectual, become more competitive in the global economy.

Competitive Aggressiveness: To affirm how competitively aggressive the operators of the artisanal refineries are, an ex-aggitator said, "in the local parlance, we hear people say 'warri no de carry last' (translated to mean that the people of Warri - a tribal group in the Niger Delta are very audacious). Stakeholders generally agree that the operators of the artisanal refineries exhibit competitive aggressiveness and the will power to pursue their venture against all odds. But competitive aggressiveness is a socially acquired attribute when it is part of the social fabric of a nation, it propels industrialization. This according to the outcome of the analysis is the main 
stay of the rural oil economy in a number of Nigerian communities. Bringing this 'never-say-die' spirit into commerce and industry, stakeholders believe is the driving force behind the operators of the illegal artisanal oil refineries. These operators are able to dare all odds to carry on with this illegal business.

With these entrepreneurial orientation tendencies, the locals are able to sustain the operations of the illegal artisanal oil refineries in spite of government's hard stance against the operations of illegal refineries. Having examined the five entrepreneurial orientation tendencies on the basis of the textual analysis of the qualitative data, we next examine how the management of these entrepreneurial orientation tendencies can lead to the creation of a serene oil economy that can guarantee national development.

\section{Management of the Entrepreneurial Orientation Tendencies for National Development}

The entrepreneurial orientation tendencies so far discussed does not develop by chance. It must be consciously cultivated and managed, and this is usually dependent on the general philosophy held by society. In other words, society sets the tone for entrepreneurship to thrive. According to Ivancevich et al (1997 p. 503), "a nation's environment has a significant impact on the level of entrepreneurship". Ahiauzu (2003 p. 6) corroborates this view by stating that "entrepreneurs are human beings operating within societies that define, and are defined by, cultures, and as such, entrepreneurs are necessarily the product of their cultures that mould and influence their actions". Thus the appropriate foundation for entrepreneurial activities must emerge from the socio-cultural milieu. Two key factors that prompt creativity and innovativeness are necessity and opportunity. Ahiauzu (2009), drawing from the work of Reylolds et al (2001) distinguishes between necessity entrepreneurship and opportunity entrepreneurship on account of push and pull motivations respectively and these motivations form the entrepreneurship environment. With the experience of the illegal artisanal oil refineries in Nigeria's Niger Delta region, stakeholder are unanimous in their view that if the right legal and economic framework is put in place, the illegal business of refining stolen crude could be rightly modeled to salvage the comatose oil industry in Nigeria. For instance, a community leader asked: "what stops government from giving licenses to these local refineries to operate or what stops them from officially allocating crude to these operators of the so called illegal refineries to legitimately refine?" Experts are of the view that the refining process adopted by these illegal operators is crude and hazardous to the environment, but several ex-agitators wonder why the entrepreneurial orientation tendencies exhibited by the operators of the artisanal refineries cannot be harnessed and put to good use by the Nigerian government. There is the need to develop an entrepreneurial environment to foster a stable oil 
economy by identifying unique peculiarities to produce an ideal structure for the country's industry. Drawing from the suggestions of Mbigi and Maree (2005), there is the urgent need for the development of cooperative and competitive people, perspectives, processes, procedures, institutions, and products and services. These will have direct impact on Nigeria's economy.

Currently, Nigeria imports over $80 \%$ of the petroleum products required for domestic consumption. Hulsmann (1999) argues that "economic growth is determined by two elements, (a) by the available quantities of goods that can be used in the productive process and (b) by the adroitness with which these available factors of production are combined". This clearly explains the inevitability of entrepreneurship for economic growth. "Entrepreneurship is increasingly being recognized as a primary engine of economic growth" (Henderson, 2007, p.2). This suggests an association between entrepreneurship and economic growth and according to Henderson (2007, p.2), this position is also held by the Global Entrepreneurship Monitor, which "indicates that nations with higher levels of entrepreneurial activity enjoy strong economic growth". Reports from government agencies like the Small and Medium Enterprise Development Agency of Nigeria (SMEDAN) and the National Bureau of Statistics agree that if the right atmosphere is created for entrepreneurship to thrive, Nigeria's growth will be rapid. For instance the SMEDAN and the National Bureau of Statistics collaborative survey of 2013 concluded that the key to the economic emancipation of Nigeria is "firmly dependent upon a structured and orderly development of the (Micro, Small and Medium Enterprises) MSME sector" (p.20). This conclusion is similar to that of Dejardin (2000 p.2) who also confirms this link by asserting that "an increase in the number of entrepreneurs leads to an increase in economic growth".

Similarly, entrepreneurship has been associated with economic development. Todaro and Smith (2006, p.102) state that development is "a multidimensional process involving the reorganization and reorientation of entire economic and social systems". Expatiating on a similar view expressed in Todaro (1977), Ajala and Aguda (2006, p.24) argue that development focuses "not only on income and output but includes radical changes in institutional social and administrative structures as well as in people's attitudes, customs and beliefs, which will lead to a visible improvement in the quality of life of the people". To this end, the Commission for Africa (2005) proposes that one way to improve a nation's investment climate is by unleashing their entrepreneurial potentials.

Nigeria's economy has been experiencing dwindling fortunes with unemployment and poverty levels reaching a record high. Violent agitations in the Niger Delta have disrupted economic activities in the area. But this situation can be partly addressed by leveraging on the positives of the 
operations of the artisanal oil refineries without entertaining economic crime and insecurity. The entrepreneurial potentials in Nigerians have been vividly demonstrated in the operations of the illegal artisanal refineries and what is left is for government to harness the entrepreneurial orientation tendencies for positive ventures to enhance economic growth and development. This is important because the UNDP evaluation office report, Essentials (1999, p.1), states that:

in developing countries, the primary barrier to economic growth is often not so much a scarcity of capital, labour or land as it is a scarcity of both the dynamic entrepreneurs that can bring these together and the markets and mechanisms that can facilitate them in this task.

This study therefore proposes that the entrepreneurial orientation tendencies within the context of the existing socio-cultural milieu, which includes family life and child rearing practices, informal education, and traditional management practices in Nigeria should be structured to create an entrepreneurial environment (i.e. how Nigerians respond to both opportunities and necessities). This will strengthen the value creation chain, which ultimately will enhance national development (i.e. economic growth and economic development).

\section{Conclusion}

This study has established on the basis of the idiographic methodology adopted that as stakeholders harness the entrepreneurial orientation tendencies demonstrated in the artisanal oil refineries, the ensuing entrepreneurial environment including opportunity and necessity entrepreneurship, will lead to enterprise development, value creation, and ultimately national development. Thus, the study recommends that beyond dealing with the crime surrounding the establishment of the artisanal oil refineries, there should be a concerted effort to manage the entrepreneurial orientation tendencies exhibited by the operators to enhance national development. For, in $\mathrm{Al}$ Maktoum's (2012) view, what is required to compete globally is excellence in delivery of goods and services.

\section{References:}

Ahiauzu, A. I. (1999). The African Industrial Man. Port Harcourt: CIMRAT. Ahiauzu, A. I. (2003). Developing functional entrepreneurial culture in the African society. CIMRAT Seminar paper, 1, 1-12.

Ahiauzu, A. (2009). Entrepreneurship and economic development in Nigeria: The way forward. Nigeria Academy of Management Journal, 3 (1), 1-18. 
Ajala, O. A. \& Aguda, A. S. (2006). Development inequalities in Osun State, Southwestern Nigeria. European Journal of Social Sciences, 2 (1), 22-37.

Al Maktoum, M. B. (2012). My Vision: Challenges in the Race to Excellence. Dubai: Motivate Publishers.

Ake, C. (1996). Democracy and Development in Africa. Ibadan: Spectrum Books Limited.

Asawo, S. P. (2011). Corporate integrity and company-community conflict management in the Niger Delta region of Nigeria. Journal of Leadership, Accountability and Ethics, 8 (3), 77-88.

Attah, T. (2012). Oil theft and artisanal (illegal) refining in Nigeria - scale, impacts and the need for a multi-dimensional response. Paper presented to the Chatham House - Gulf of GUINEA Security Conference, London. www.shell.nl.media.par.textimage.file (accessed 8 March, 2015).

Barringer, B. R. \& Ireland, R. D. (2013). Entrepreneurship: successfully launching new venture. Boston: Pearson.

Bateman, T. \& Snell, S. A. (1999). Management: Building Competitive Advantage. Boston: Irwin McGraw-Hill.

Boohene, R., Marfo-Yiadom, E. \& Yeboah, M. A. (2012). An empirical Analysis of the Effect of Entrepreneurial Orientation on Firm Performance of Auto Artisans in Cape Coast Metropolis. Developing Country Studies, 2 (9), 77-86.

Boris, O. H. (2015). The upsurge of oil theft and illegal bunkering in the Niger Delta Region of Nigeria: is there a way out? Mediterranean Journal of Social Sciences, 6 (3 s2), 563-573.

Colombatto, E. (2006). On Economic Growth and Development. Review of Austrian Economics, 19, 243-260.

Commission for Africa, (2005). Our Common Interest, Report of the Commission for Africa.

Derah, G. G. (2001). The socio-economic and political challenges of the Niger Delta. In Ozo-Eson, P. I. \& Ukiwo, U. (eds.). The Niger Delta Development Commission: towards Development Blueprint, Centre for Advanced Social Science (CASS), Port Harcourt.

Dejardin, M. (2000). Entrepreneurship and Economic Growth: an obvious Conjunction? Publication Series, The Institute for Development Strategies, Indiana University, Indiana.

Drucker, P. F. (1985). Innovation and Entrepreneurship. Oxford: Butterworth Heinemann.

Efemini, A. O. (2002). A critical reflection on development rights in the Niger Delta. In Wokocha, R. A. (eds.). Challenges of the Niger Delta, Schalesworths, Centre for Democracy and Development, Port Harcourt. Ekuerhare, B. (2002). Sustainable development models for the Niger Delta region. In Ozo-Eson, P. I. \& Ukiwo, U. (eds.). The Niger Delta Development 
Commission: towards Development Blueprint, Centre for Advanced Social Science (CASS), Port Harcourt.

Fubara, B. A. (2002). The politics of the Niger Delta, in Ozo-Eson, PI and U Ukiwo (2001). The Niger Delta Development Commission: towards Development Blueprint, Centre for Advanced Social Science (CASS), Port Harcourt.

Gannon, M. J. (1988). Management: Managing for Result, Boston: Allyn and Bacon Inc.

Henderson, J. (2007). Understanding rural entrepreneurs at the county level: data challenges. Paper presented at the Frameworks for Entrepreneurship Research in Food, Agriculture and Rural Development workshop, Kansas City.

Hofstede, G. (1996). Cultural constraints in management theories, in Steer, RM, LW Porter and Bigley, G. A. (1996). Motivation and leadership at work. New York: McGraw-Hill.

Hofstede, G. (1997). Culture and organizations. New York: McGraw-Hill.

Hulsmann, J. G. (1999). Entrepreneurship and economic growth: comment on Holcombe. The Quarterly Journal of Austrian Economics, 2, 63-65.

Ivancevich, J. M., Lorenzi, P., Skinner, S. J, \& Crosby, P. B. (1997). Management: Quality and Competitiveness. Boston: Irwin McGraw-Hill.

Mbigi, L. (1997). Ubuntu: The African Dream in Management. Randburg: Knowledge Resources.

Mbigi, L. \& Maree, J. (2005). Ubuntu: The Spirit of African Transformation Management. Randburg: Knowres Publishing.

Mintzberg, H. (1989). Management. New York: The Free Press.

Nwinia, C. S. (1993). Economic and Financial Development: a conceptual and structural Review, Ibadan: Kraft Books Limited.

Ofehe, S. (2009). Visit to an illegal local crude oil refinery in the creeks of the Niger Delta. Road to Niger Delta Peace Conference tagged "Hague 2009”: Report on Journey and Progress so far made, Hope for Niger-Delta Campaign. www.ofehe.com.report3 (accessed 8 March, 2016).

Okpara, FO (2007). The value of Creativity and Innovation in Entrepreneurship. Journal of Asia Entrepreneurship and Sustainability, 3 (2), 1-14.

Sarasvathy, S (2001). Causation and effectuation: toward a theoretical shift from economic inevitability to entrepreneurial contingency. The Academy of Management Review, 26 (2), 243-263.

Small and Medium Enterprises Development Agency OF Nigeria (SMEDAN) and National Bureau of Statistics Collaborative (2013). SMEDAN and National Bureau of Statistics Collaborative Survey: Selected Findings.

Stockes, D and N Wilson (2010). Small Business Management and Entrepreneurship. Australia: South-Western CENGAGE Learning. 
Strauss, AL and JM Corbin (1990). Basics of Qualitative Research: Grounded Theory Procedures and Techniques. Newbury Park, CA: Sage Publications. Todaro, MP and SC Smith (2006). Economic Development. Harlow: Pearson Addison Wesley.

United Nations Development Programme (UNDP) (1999). Entrepreneurship Development. Essentials, 2, 1-12.

Wokocha, RA (2002). Development right concerns in the Niger Delta region of Nigeria, in Wokocha, RA (2002). Development Rights Issues in the Niger Delta, Schalesworth Centre for Democracy and Development, Port Harcourt. Weiss, RS (1994). Learning from Strangers: The art and Method of Qualitative Interview Studies. New York: Free Press.

Yew, LK (2000). From Third World to First: The Singapore Story: 1965 2000. New York: Harper Collins Publishers. 